\title{
Manuscript Collections: The A. J. Van Duzee Papers
}

\author{
David Crosson
}

To anyone even vaguely familiar with the collecting reputation and acquisitive abilities of Gene M. Gressley, it is not surprising to find an excellent collection of manuscripts on midnineteenth century lowa in the Division of Rare Books and Special Collections of the University of Wyoming, Laramie. More spectacular finds than this have been plucked from their natural habitats and spirited off to the temple on the tundra. A researcher's time and effort is often rewarded many times over by investigating archival holdings beyond the state's borders. He may turn up research materials of value and insight-such as the Alonso J. Van Duzee Papers at the University of Wyoming.

THE "WeSTWARD MOVEMENT" has become one of those grand institutionalized phrases of American history, so grand and general and accepted as to become almost meaningless. Textbooks picture a giant stain spreading out over a map of the continent, blotting out not only the aboriginal names the movement overwhelmed, but also the individual people who participated in it. A few stellar lights are remembered: Boon, Grinnell -men who colonized and promoted. But, in general, the 


\section{The Annals of Iowa}

"Westward Movement" is seen more as a force, a long-term event, than a process.

And process it was, a process of hundreds of thousands of individuals and families uprooting, moving, replanting themselves, moving again, dying, moving, not knowing that they were part of a movement. People decided to go West not out of a sense of destiny, although that may have been the ex post facto rationale of the politicians and remains the hindsight wisdom of some historians. Individuals, families, large and small groups of people decided to move west the same way they decided to move anywhere else-across the street, down the pike, south, north, or across the ocean-for very real, personal, concrete reasons. For some, moving west was a hope for improvement. For others it was necessitated by simple economics, fortune (good or ill), or even family ties. For whatever reasons, moving west involved real people in very real problems, problems that individually are never quite as grandiose as the textbook headlines might suggest.

Some time in 1847 Isaac Newton of Shelburn, New York braved the Great Lakes, mud-troughs called roads, and uncertain river travel to seek his fortune as a surveyor and civil engineer in Iowa Territory. He returned to the East in 1848 to marry Eliza Van Duzee in Swanton, Vermont, and bring her back to a house south of Dodge Street, in Dubuque. Isaac was apparently high on his new home, for he convinced Eliza's younger brother, Alonzo Van Duzee, to trek to Dubuque in 1850 to seek his fortune with them in the West.

This is how the Van Duzee migration to Iowa began. Eliza's move in 1848 and Alonzo's two years later encouraged their father Ira to move with his youngest son to the Hawkeye State in 1852. The youngest brother, Edward, was particularly anxious to avoid the family marble business in upstate New York, but every member of the family had reasons for moving. As new personal situations arose, some moved again, and again. The Van Duzee saga is the real Odyssey of the "Westward Movement" at the individual, personal level. The Van Duzee Collection of manuscripts at the University of Wyoming helps give meaning to what otherwise too often remains a glowing historical abstraction. 
The Ira Van Duzee family had periodically quarried and sold marble in Gouverneur, New York for years. Ira, his brothers, and cousins also worked in similar operations in Swanton, Vermont, and other Empire State communities between Buffalo and the Blue Mountains. From the number of times the families moved or husbands lived apart from their families, employment must have been seasonal and the work must have been hard. It is not difficult to imagine why Ira and his sons would have liked to exchange lives of such labor and uncertainty for at least the opportunity to achieve something better.

Isaac Newton's move to Iowa offered the Van Duzee family the promise of improvement. The children were the first to respond, but the father, perhaps partially to retain some control over his offspring, acted upon the opportunity, too. So, the entire family entered the Beautiful Land through what was then Iowa's most prominent city, Dubuque. From there, they dispersed farther.

Ira Abraham Van Duzee was born in upstate New York in 1798 and had five children by two wives. William, Eliza, Edward, and Alonzo either preceded him to or joined him in Iowa. Only Eliza and Alonzo remained in the Hawkeye State. Ira had early joined a family marble business in Gouverneur, New York and had worked in various enterprises of a similar nature. The various locations of the correspondence would suggest that Ira went wherever he could locate money for whatever time he could retain it. He followed his daughter and middle son to Iowa in 1852, but quickly moved to Anoka, Minnesota, finally settling in Hastings, where he discovered a bustling foundry at which he could work, while supplying local lumber needs and working a small farm.

Ira Van Duzee's oldest son William stayed in New York with his burgeoning family - more difficult to move than single sons or bachelor quarters - until 1855, when he moved to Hastings, Minnesota, where his father had then settled. William soon found employment as a joiner and foundry worker, all under considerably improved conditions than he had known in New York. After his wife's death in 1863 and an unfortunate second marriage, he moved to Minneapolis, where he served as City Surveyor and Street Commissioner from 1870 until his death. 


\section{The Annals of Iowa}

Edward, the youngest brother, stayed with his father until 1859 , when he moved back to Dubuque, and finally to Independence, where he established a prosperous law practice. But the Civil War disrupted his success, and he enlisted with the Twelfth Iowa Volunteers, in which he was elected a captain and mustered out as a major. He returned to Independence to find all the legal business absorbed by other attorneys. So, for economic reasons, he moved again, first to Anoka, Minnesota, with his father, then to Dubuque with his brother, and finally to Minneapolis, where he became an insurance representative and eventually a St. Paul bank executive.

Through this all, Alonzo remained in Dubuque and flourished as a merchant. He, too, entered the War, as Regimental Quartermaster for the one-hundred day Forty-Fourth Iowa Infantry. During that one hundred days in the field, his wife died at home.

The Alonzo J. Van Duzee Collection at the University of Wyoming is actually a genealogical collection for the entire Van Duzee family. It contains five major groups of letters, although the logic of the groupings is not evident: (1) ten letters to A. J. Van Duzee from his father and mother, 1862-67; (2) thirteen letters concerning missionary work, 1861-85; (3) forty-four family letters from 1808-59; (4) sixty-five family letters from 18601932; and (5) a group of 1861-64 family letters.

The collection also contains A. J.'s 1864 combat diary, a detailed "Genealogy of the Van Duzee Family," a number of Iowa legal papers, three Civil War military requisitions, some photographs, and Edward Van Duzee's original manuscript, "Incidents of Prison Life in 1862." Originally published in the Annals of Iowa, Ser. 1, vol. 6, 1868, Edward's memoirs are important to remind us that not all prisoner experiences in the South were of the Andersonville caliber.

Taken as a unit, The Van Duzee Collection provides an intimate glimpse of the westward progress of one family. It allows the researcher to explore why they moved, the mechanics of moving, the everyday lives of plain, non-spectacular people. One can see William's wife "experience religion" at a Buffalo revival in 1852. The reoccurrence of death and illness reminds us of the anguish that was once a constant presence in people's 


\section{Manuscript Collections}

lives. How can one be unaffected by the description of William Van Duzee's mother of the death of her daughter-in-law?

Just before she breathed the last, her eyes opened wide, and she seemed to see the glories of another world. William is very much broken down. I could not believe he could be so much overcome. - She said she wished to talk to the children, but could not. She only looked at them. She said "Be Good." After that she kept hold of William's hand, with her eyes fixed on him, until they were fixed upon celestial things.

This is the type of historical research collection that brings meaning to "greater" things. It brings history into focus, because it lights up the lives of everyday folk, like us, in everyday situations. The times they be a changin', but the people, they are stayin' the same. And that is reassuring to know. 
Copyright of Annals of Iowa is the property of State of Iowa, by \& through the State Historical Society of Iowa and its content may not be copied or emailed to multiple sites or posted to a listserv without the copyright holder's express written permission. However, users may print, download, or email articles for individual use. 